\title{
Influence of Climate Temperature on the Valorization of Dung-Wastewater Slaughterhouse Biogas in Two Regions: In Chad and Senegal
}

\author{
Haroun Ali Adannou 1,2, Saka Goni1,3, Mahamat Bichara Abderaman 1,2, \\ Mahamoud Youssouf Khayal ${ }^{4}$, Ache Abouya Khamis ${ }^{2}$, Moulaye Aidara ${ }^{5}$, \\ Talla Kharouna1, Aboubaker Chedich Beye ${ }^{1}$ \\ ${ }^{1}$ Department of Physics, Faculty of Science and Technology/Cheikh Anta Diop University of Dakar, Dakar, Senegal \\ ${ }^{2}$ Department of Chemical Engineering, National Institute of Petroleum of Mao, Mao, Chad \\ ${ }^{3}$ Department of Industrial Engineering and Maintenance, Polytechnic University of Mongo, Mongo, Chad \\ ${ }^{4}$ Virtual University of Chad, N'Djamena, Chad \\ ${ }^{5}$ Panafrican Institute for Online Education, Dakar, Senegal \\ Email: harounali100@gmail.com,saka_goni@yahoo.fr,moulzo@yahoo.com
}

How to cite this paper: Adannou, H.A., Goni, S., Abderaman, M.B., Khayal, M.Y., Khamis, A.A., Aidara, M., Kharouna, T. and Beye, A.C. (2019) Influence of Climate Temperature on the Valorization of Dung-Wastewater Slaughterhouse Biogas in Two Regions: In Chad and Senegal. Natural Resources, 10, 81-95.

https://doi.org/10.4236/nr.2019.104006

Received: March 1, 2019

Accepted: April 19, 2019

Published: April 22, 2019

Copyright (c) 2019 by author(s) and Scientific Research Publishing Inc. This work is licensed under the Creative Commons Attribution International License (CC BY 4.0).

http://creativecommons.org/licenses/by/4.0/

\begin{abstract}
In this work, we have produced biogas by co-digestion of cow dung and slaughterhouse wastewater under different climate temperatures in two countries: N'Djamena in Chad, a country of Central Africa and Dakar in Senegal, a country of West Africa. In a first approach, we put the cow dung in cans of $1.5 \mathrm{~L}$, hermetically closed. The goal was to know how long you could produce biogas. Then we built a bio-digester to produce biogas for cooking. Each bio-digester was exposed to receive solar heat that varied between $27^{\circ} \mathrm{C}$ to $41^{\circ} \mathrm{C}$ in Chad and between $24^{\circ} \mathrm{C}$ to $30^{\circ} \mathrm{C}$ in Senegal. Influenced by the high temperature and a minimum residence time, the experiments showed that the N'Djamena test produced biogas more quickly than the Dakar test which, on the contrary, had a low temperature and a long residence time. The production of biogas began at the end of seven days with flammability on the twenty-first day for the bio-digester in Chad and after twenty-seven days with a flammability on the thirty-sixth day for the bio-digester of Senegal. The different digestates were valorised in fertilizers, bricks and green coal. Our research aims to meet the living conditions of the rural world specifically for women by reducing their work and thus allowing them to have more time to self-educate and educate their children.
\end{abstract}




\section{Keywords}

Co-Digestion, Climate Temperature, Cow Dung, Slaughterhouse Wastewater, Biogas, Digestat, Rural World, Self-Education

\section{Introduction}

Anaerobic digestion is a versatile biotechnology for converting organic waste into valuable biogas. One of the most profitable aspects of anaerobic digestion of manure allows both the production of bioenergy and the production of nutrient-rich soil amendment [1], because the presence of ammonia in the digestate is interesting for the production of ammonium sulphate, a fertilizer that promotes plant growth [2], reduction of greenhouse gas emissions and odor control [3] [4], it is therefore consistent with agricultural practices [5] [6] and the environment as well as the adaptation to climate change of different crops that can not only feed a whole population but contribute significantly to the production of biomass very favorable to biogas [7] [8]. This anaerobic digestion must take place in an enclosure called anaerobic bioreactor or fermentor consisting of a closed tank, airtight and preferably thermally insulated from the outside, in which different bacterial species take turns to degrade the organic waste compounds, or effluents and produce biogas [9] [10], mainly composed of methane but also carbon dioxide [11], while halving the level of organic matter represented by biodegradable by-products [12] [13]. This oxygen-free medium must respect several parameters in order to lead to a different optimized and controlled reaction to produce biogas that can be recovered in various forms [14] [15]. Among these parameters, temperature is one of the most sensitive elements to good biogas production. Our study focuses on the possibility of producing biogas under the influence of climate temperature in two regions of Africa with a completely different climate.

The study conducted by [16] examined the temperature dependence of $\mathrm{CH}_{4}$ emissions from pre-storage of animal manure prior to anaerobic digestion at $15^{\circ} \mathrm{C}, 20^{\circ} \mathrm{C}, 25^{\circ} \mathrm{C}$ and $30^{\circ} \mathrm{C}$ using anaerobic digesters in the laboratory. Research has shown that with minimal temperature and adding waste into the digester $\mathrm{CH}_{4}$ emissions can be reduced, but with high storage temperature these emissions are increased. Thus, in mesophilic or near-mesophilic temperature conditions, cow dung has a high biogas production potential [17]. The environmental benefits of using digesters for low-cost biogas and low-cost digestate production in small-scale farms would significantly reduce (up to $80 \%$ ) the potential environmental impacts associated with handling stored and non-upgraded manure, the use of fuel liquefied petroleum gas (LPG) used for cooking and also synthetic fertilizer used in crops [18]. The aim of this research is to respond, on the one hand, to the low energy supply rate of rural populations in Chad and, on the other hand, propose an easy digesters assembly technique. The low energy 
supply rate in developing countries, which is also a major handicap for their socio-economic and environmental development [19], is attracting increasing interest. Several countries in Asia and Africa, including China, India, Nepal, Bangladesh, Cambodia, Vietnam, Kenya, Rwanda, Tanzania, Burkina Faso and Senegal are launching massive campaigns to promote biogas technology [20] [21]. Chad for its part remains by far the technology and/or the applicability of this resource. Faced with a growing population, the consumption of biogas energy can contribute to the problem of women's poverty, especially in rural areas, where people prefer to cook by cutting trees [22]. In addition, the energy use of wood has a negative impact on women's health because of the smoke released during cooking. The use of biogas helps to significantly reduce the time and labor of women, which could be used for other productive purposes, and to improve their health [23]. Our case study is based on animal waste mainly cow dung but could also consider any other type of livestock waste or other with a good methanizable potential. Thus, Chad is a country of breeding par excellence, however this breeding generates an impressive quantity of waste but unfortunately the techniques and the knowledge of the valorization of the latter remain poorly known. Until May 3, 2018 The Chadian herd counted 113,560,000 head of cattle and 34.6 million head of poultry. The "livestock" group consists essentially of ruminants such as goats (32.5\%), sheep (28.2\%), cattle (26.5\%) and camels $(6.8 \%)$. Poultry was dominated by chicken farming with 26.6 million head, or $77 \%$ of the total. Other poultry are ducks, geese, guinea fowl and pigeons. These figures put Chad in third place in Africa in terms of livestock and could thus become the main engine of the Chadian economy. Its modernization would be a great breeding ground for rural employment and an important source of diversification of processing activities of livestock by-products [24]. Chad, although having a significant energy potential, it is difficult to obtain precise data on the use or application of solar energy and biogas, only a society uses its waste in electricity. Of the Sarh Sugar Corporation using sugar cane bagasse to convert this biomass into electrical energy, wood is the main source of cooking energy used by $75 \%$ of households in urban areas [25]. In Senegal, livestock is an important part of its economy. Like agriculture, it is one of the main income-generating and employment-generating activities of rural populations [26]. The biogas initiative launched by the Government of Senegal, in collaboration with some international organizations, was to develop bio-digesters as commercially viable products to reduce poverty and improve health by reducing the pollution associated with firewood, reducing deforestation and producing digestate as an alternative to inorganic fertilizers in rural areas. The Senegalese government's biogas program, which targeted the installation of 8000 digesters between 2009 and 2013, has not achieved its objectives, with fewer than 600 units built. One study found that the development of clean cooking fuels in Senegal is hampered by poorly designed and poorly implemented government policies and by the structural and endemic poverty of rural people, particularly farmers who are mainly involved in agriculture and agriculture. Breeding. She 
proposes to solve the problem by proposing a new paradigm combining livestock breeding, income generation and market-oriented domestic biogas production to provide farmers with clean cooking energy through biogas digesters [27].

\section{Materials and Method}

\subsection{Materials and Substrate}

During our work we used a substrate that was cow dung taken directly to the local cattle market in N'Djamena and Dakar and waste water from slaughterhouses in different countries. We present a photograph of the substrate in Figure 1.

The mounting equipment consisted of: A number 13 car air chamber; a 301 can serving as a digester; a garden hose; a fitting adapted to the pipe; two (2) T-fittings; two (2) single fittings; two (2) brass nipple; a sealing ring; a burner or stove; a $6 \mathrm{~mm}$ gas pipe; a tap and safety valves.

After assembly we have this.

Figure 2 shows the diagram of the bio-digester used for the production of biogas with these different components.

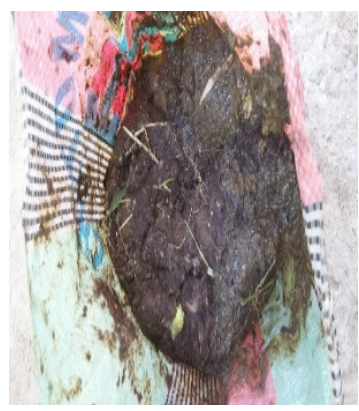

(a)

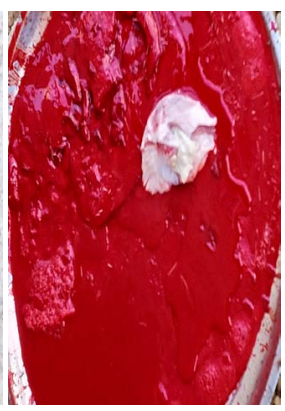

(b)

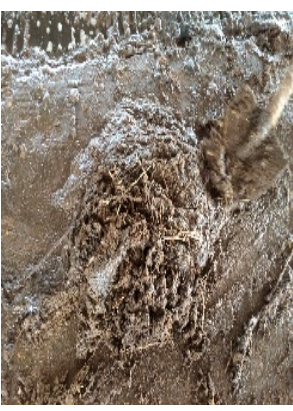

(c)

Figure 1. Substrate photography. (a) Cow dung N'Djamena; (b) slaughterhouse waste (blood and gut content); (c) Cow dung Dakar.

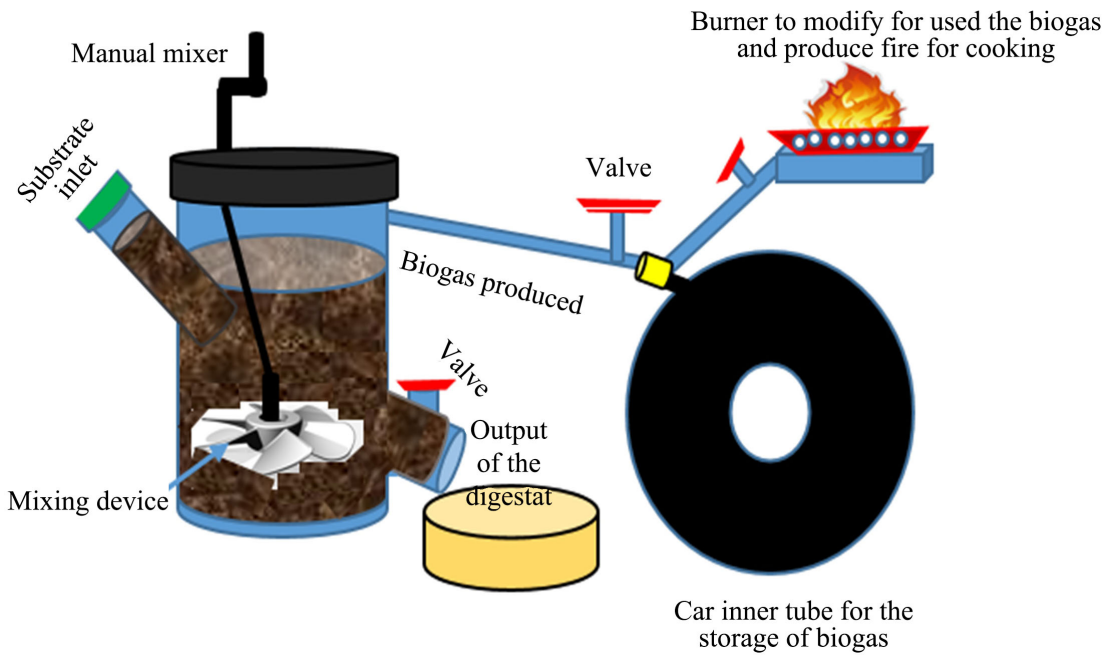

Figure 2. Diagram of the bio-digester. 


\subsection{Method}

The assembly of bio-digesters followed the method described by [28]. Once completed, we filled the water digester for safety reasons related to any escape. The lack of flow allowed us to implement our production. The water is then removed from the digester tank by the digestate discharge part. For the implementation of the introduction of the substrate and the production of biogas, the method used consists in producing an intermediate sample which will be used as a base for the production of biogas, the volume/mass of which is conditioned by the type of analysis to achieve. Then we calculated the density.

The formula for calculating the density is as follows:

Density $=($ Sample mass - Curb weight containing $) /$ Volume of the weighed substrate.

Units:

- Mass of the sample: in kilograms.

- Mass of the container: in kilograms.

- Volume of the substrate: in liter.

Cow dung is weighed for a specific mass. Slaughterhouse waste water is added and the mixture is mixed in a vat to allow the dung and water to form a homogeneous mixture. For our use as a 301 digester, we took a mass of cow dung representing less than $1 / 3$ of the summer and a volume more than $2.5 / 3$ of water. The whole of our mixture is evaluated to 281 in ours was of a capacity of 301 . A water content such as the weight of water represents $90 \%$ of the weight of semi-solid raw materials [29]. The upper part was thus left for the gaseous cloud that should pass through the pipe connecting the digester and the air chamber used for storing biogas. Once weighed and mixed, we introduce the substrate into our digester by the part dedicated to this action. For this part we have adopted the methodology of written by [30] and [31]. The volume of our system being known, we made a calculation approach previously described by [32] but our results according to the experience made in Chad are different from that of Senegal. The $\mathrm{pH}$ was measured initially on the substrate before introduction and at the outlet of the digestate with a $\mathrm{pH}$-meter of the type "Preciva Pen type PHmeter" Model: PH3200001. The temperature is measured daily with a thermometer type "Infrared thermometer $-50^{\circ} \mathrm{C}-400^{\circ} \mathrm{C}$ ".

\section{Result and Discussion}

\subsection{Measurement of the Ambient Temperature}

Each bio-digester was exposed to receive solar heat that varied between $27^{\circ} \mathrm{C}$ to $41^{\circ} \mathrm{C}$ in Chad and between $24^{\circ} \mathrm{C}$ to $30^{\circ} \mathrm{C}$ in Senegal.

\subsubsection{Case of Chad}

The experiments were done in both countries in hot season, so for Chad the very hot season lasts 2.3 months, from March 18th to May 27th, with a maximum average daily temperature above $39^{\circ} \mathrm{C}$. The hottest day of the year is April 15, with a maximum average temperature of $41^{\circ} \mathrm{C}$ and a minimum temperature of $26^{\circ} \mathrm{C}$ 
[33] In terms of measurements, work began from March 21, 2016 to May 20 2016. We present the measurements of the ambient temperature as a function of the retention time in Chad in Figure 3.

Chad is in the upper sun zone of Africa. The number of hours of sunshine per year varies from 2850 hours in the south to 3750 hours in the north of the country. The intensity of global radiation varies on average from 4.5 to 6.5 $\mathrm{kWh} / \mathrm{m}^{2} / \mathrm{d}$. [25] the production temperature of the biogas for the experiment made in Chad is close to that of [34] which for their part had a co-digestion between cow dung and water hyacinth.

\subsubsection{Case of Senegal}

In Dakar, the maximum average is $24^{\circ} \mathrm{C}$ from January to March and between $25^{\circ} \mathrm{C}$ and $27^{\circ} \mathrm{C}$ in April, May and December. From June to October, temperatures reach $30^{\circ} \mathrm{C}$ [35]. We started our work from June 2nd to August 2nd 2017. Figure 4 shows the measurements of the ambient temperature as a function of the retentio time of the biogas production in the Dakar digester in Senegal.

The production temperature of our biogas for the experiment in Senegal is close to that of [36] who had rather co-digested cow dung with a corn husk for the production of biogas at the laboratory scale. The curves in both cases are about the same as those of [34].

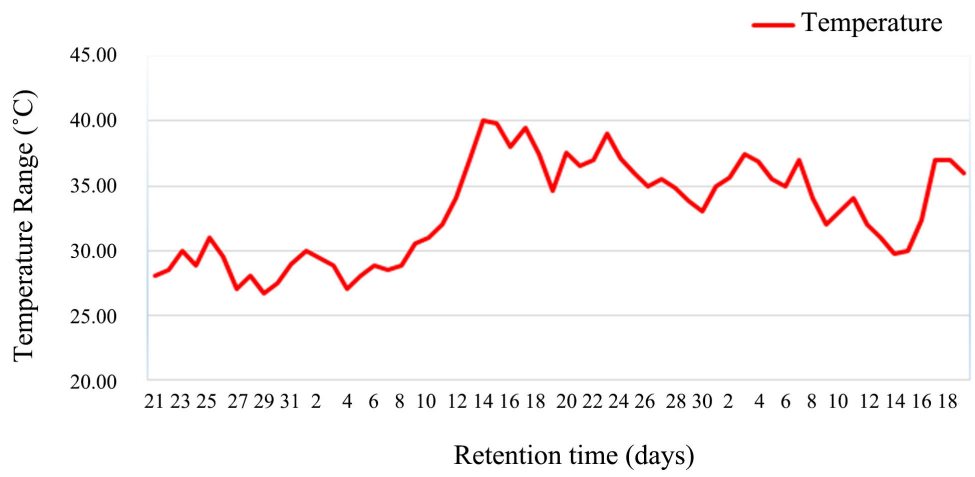

Figure 3. Temperature recorded for the production of biogas in Chad.

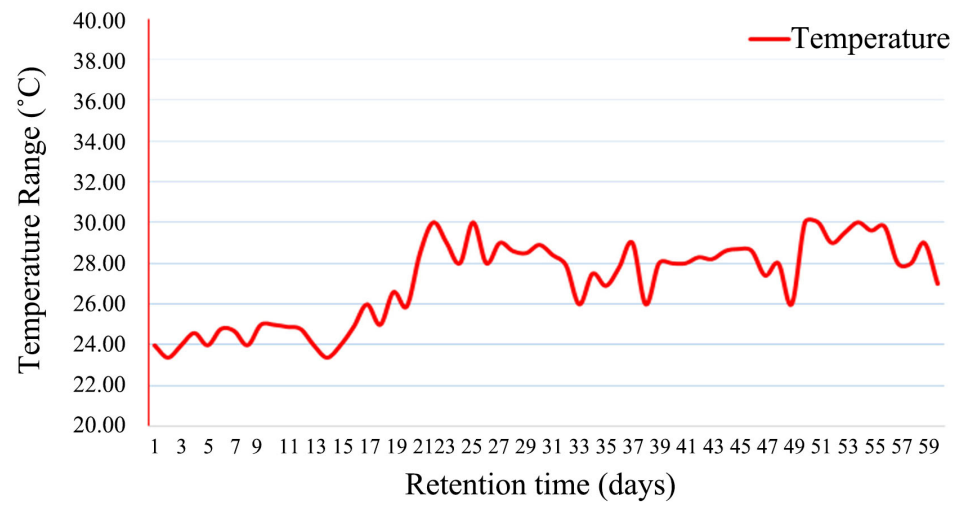

Figure 4. Temperature recorded for biogas production in Senegal. 


\subsection{Effects of Climate Temperature on Biogas Production in Rural Areas}

The population in rural areas does not benefit from liquefied petroleum gases for cooking, they cut trees for firewood and coal.

This excessive cutting of trees causes deforestation and global warming. But most importantly makes women work harder and affects their health. To produce biogas, it is necessary to have a sufficient temperature capable of influencing the treated substrate and to convert the various stages of production of bio methane into biogas. The results of this article prove that with the ambient temperature of the climate we could produce biogas used for cooking. It is true that during hot weather the production of biogas is accelerated and during cold weather it can be delayed. However we are considering a solution in the cold time interval. Among other things, this solution would be to use sensors capable of transforming solar radiation into warmer temperature in the digesters, thus creating a serf process that prevents radiation and the heat entering from emerging.

A second case of solution would be to use solar radiation to create a stirring mechanism via a sensor that will provide energy capable of rotating a crank that will mix inside the digester. It has been shown that agitation is an important factor for biogas production. Monitoring the impact of agitation on the progress of the biogas production process is comparable to the effect of adding the inoculum from the point of view of the speed of the production process. The considerable effect of agitation in a digester is due to the fact that stirring allows the gas bubbles to be released from the deep layers, to maintain the homogeneity of the temperature at different levels and to avoid the consolidation of the crust on the surface of the digester. It promotes, in addition, the supply of bacteria in nutrients and their transport to fresh substrate, newly introduced. This positively influences the evolution of the productivity of the digester. A third example would be to use a solar water heater to either meter the digester in this water heated by solar radiation, or use this hot water to mix cow dung-slaughterhouse waste composed of blood, belly contents, fat and other. Finally one last solution would be to temporarily heat the digester with the biogas it produces. All these solutions can be the subject of different articles adapted to our context and for the simplicity of use in a rural area.

\subsection{Time of Digestion}

The time required for digestion in both cases was different. The production of biogas began at the end of seven days with flammability on day 21 for the bio-digester in Chad and after twenty-seven days with a flammability at day 36 for the bio-digester of Senegal. As for the experiment conducted in Chad, it is assumed that the digestion time was 21 days because the volume of the inner tube was observed, so the biogas was burned by period and from the twenty-first day onwards. On the fifth day, when the volume of the air chamber decreased as 
a result of the use of the biogas, the evacuation valve was opened to extract $80 \%$ of the contents and we added a fresh load of $80 \%$ in the digester. This process is repeated each weekend and Chad's bio-digester continues to produce a significant amount of biogas until the end of the experiments. For the bio-digester of Senegal the production began four weeks after the implementation of the bio-digester with a flammability noted on the thirty-sixth day. In this case, we assume that the normal digestion time took place in less than five weeks as in the case of [37]. Despite this, the quantity of biogas produced in the inner tube was lower than that of Chad.

\subsection{PH Observation}

The $\mathrm{pH}$ was determined in both cases at the beginning of the introduction of the substrate and at the end of each phase of biogas production on the digestate. We present the details of the different $\mathrm{pH}$ measured in Table 1.

$\mathrm{PH}$ is a very interesting indicator in the stabilization and the good progress of anaerobic digestion. There are several $\mathrm{pH}$ values ranging from 5.5 to 8.5 , with an optimum around 7 - 8 [38] see 8.5 [39]. Since the anaerobic digestion processes are strongly influenced by $\mathrm{pH}$, they can however take place optimally in the vicinity of neutral $\mathrm{pH}=7$ and between 6.5 and 7.5 giving a good yield for certain types of substrate and in better conditions. In our work, the results of the $\mathrm{pH}$ measured on the experiment in Chad are similar to the work of [40] and for the experiment carried out in Senegal the result is close to that of [41].

\subsection{Biogas Production and Use for Cooking in Both Cases}

In both cases of experience we used at the beginning of our activities a simple can of water of capacity of $1.5 \mathrm{~L}$. These cans were considered digesters, so before having the ideal ratio for mounting our bio-digester, several experiments were made to find the right ratio that should allow us to use it in our $30 \mathrm{~L}$ digester and produce biogas within an acceptable time interval depending on the climate of the different countries of study. We assume that biogas produces in both cases to respect all the stages of the biological mechanisms of anaerobic digestion described by [42]. A photograph of the different uses of biogas for cooking is given in Figure 5. We did not measure the amount of biogas or these physical characteristics, however, the biogas was of necessary quality cooked throughout our work in different countries and this was our goal.

\subsection{Valorization of the Digestate}

One of our objectives was also to valorize the digests obtained during the different experiments and to use them for several purposes. Thus among the types of valorization of the digestate we have three axes:

The use of digestate to fertilize the soil [2] [43]: this valuation consisted of directly using the liquid digestate in cultivated plots by following the same watering process of the plants but by preparing the growing soil in advance with the liquid digestate (Figure 6(a)). 
Table 1. pH monitoring.

\begin{tabular}{ccc}
\hline \multirow{2}{*}{ Observation $\mathbf{p ~ H}$} & \multicolumn{2}{c}{ Zone } \\
\cline { 2 - 3 } & Chad Digester & Senegal Digester \\
\hline pH entered on substrate & $7.2 \pm 0.2$ & $6.5 \pm 0.05$ \\
pH output on digestate & $8 \pm 0.5$ & $7.98 \pm 0.02$ \\
\hline
\end{tabular}

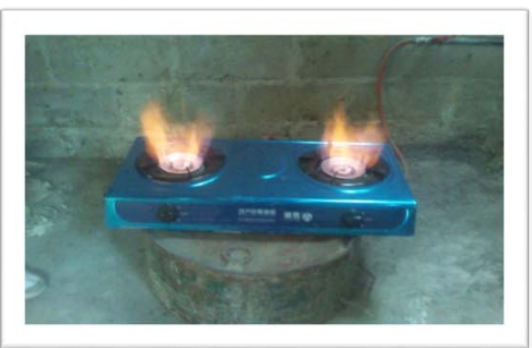

(a)

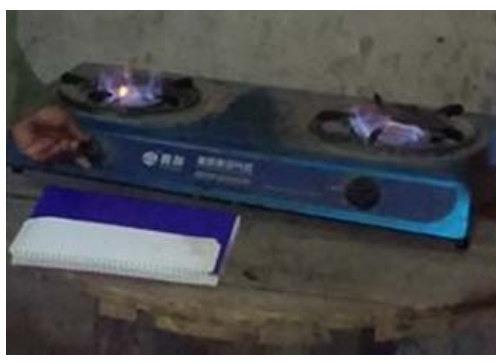

(b)

Figure 5. Photograph of stoves using fire from biogas for cooking. (a) Case of Chad; (b) Case of Senegal.

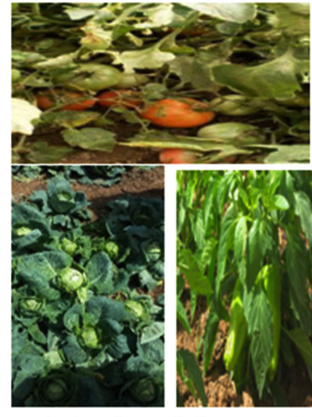

Valorization of digestate in crops

(a)

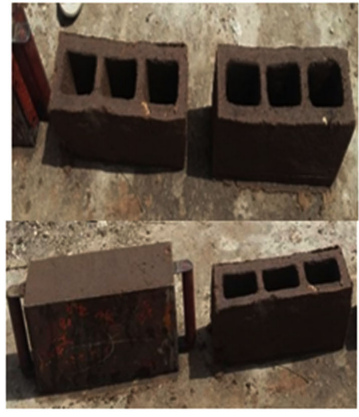

Valorization of digestate in the construction of sustainable bricks

(b)

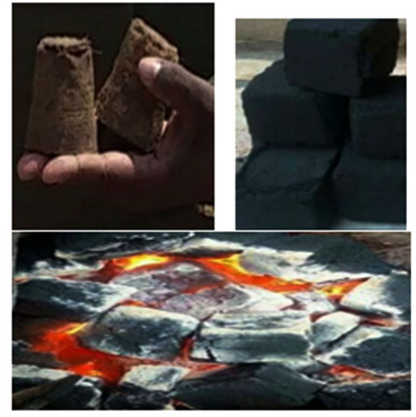

Valorization of digestate in the manufacture of sustainable coal

(c)

Figure 6. Different types of recovery of digestate.

The second area of development is the use of the solid part of the digestate in sustainable brick making for house construction in rural areas where the introduction and use of cement is still difficult: the process consists of mixing the digestate solid with black clay and dirty end to mold all in a mold used for cement bricks: for this valuation, the characteristics of the brick are still under study and we have not for the moment build a wall with (Figure 6(b)).

For the third valorization and one of the most efficient in terms of ecology and respect for the environment, we manufactured an ecological coal. The solid digestate and a liquid part were used as a basis for mixing with several other types of household waste to dry. The whole is mixed under a given temperature and exposed to the sun. Once dry, it is still mixed with the digestate and covered under a sun shelter, once the moisture content is acceptable, they are put in a pressure mold to have a shape and exposed to the sun to dry and be ready to use (Figure 6(c)). 


\subsection{Future Outlook for Sustainable Development}

In developing countries, and particularly in sub-Saharan Africa and South-East Asia, rural villages and remote areas often lack a direct link to power grids, locking them into a cycle of poverty and underdevelopment. More and more countries are nevertheless helping their fellow citizens to escape this energy trap by exploiting an unexpected and under-appreciated resource: animal dung. Poultry, pigs, sheep, cattle and other domestic animals generate about $85 \%$ of animal faecal waste. According to Elevage Mondial, turning this livestock manure into biogas offers a way to make a renewable fuel source available to more than one billion people for their home use, giving them access to sustainable, affordable and reliable energy. Chad and Senegal are both breeding countries par excellence. The graph shown in Figure 7 gives a percentage of the animals that could be used for $90 \%$ of their excrement.

This approach has already been widely adopted in India and China. Between 2003 and 2013, China built 42 million small biogas plants (from chicken manure and livestock manure) that provide energy and light and heat, as well as many power plants in the country. Biogas, much larger, with a daily capacity of 18,000 to $60,000 \mathrm{kWh}$, by 2003 , India had already installed nearly 3.4 million family-sized biogas reactors in several remote areas of the country, and by 2015 the number of family-size biogas plants across the country had risen. To four million, other countries in Asia and Africa are now exploring the use of biogas to develop household electricity production [44].

This figure (Figure 8) summarizes the importance of the use of biogas in a number of important and sustainable approaches. We propose this approach to contribute to the waste management system focused on biogas production of job creation and added value to the environmental protection mechanism in the rural world.

\section{Conclusions}

At the end of this work, we can say that the bio-digester, although a technique unknown in Chad remains, one of the best solutions for obtaining renewable energy from organic waste, which can be used as such without treatment or with treatment in the production of heat, for cooking and with treatment in gas engines and generators to produce electricity. In short, the goal of our work was to design an easy-to-use bio-digester adapted in rural areas to produce heat and prevent deforestation.

The anaerobic bioreactor makes it possible to transform volatile organic matter into energy, while preserving its fertilizing potential, both from the point of view of organic matter and mineral elements. It is therefore a way of energy recovery of products such as livestock manure and crop residues whose return to the ground is essential. If all organic wastes from the animal and plant world were recovered to exploit their fermentation gas that would be an important step for the environment. This combustible gas is obtained by the decomposition and fermentation of 


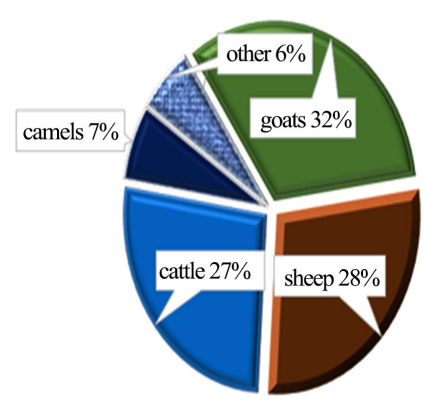

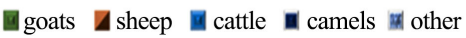

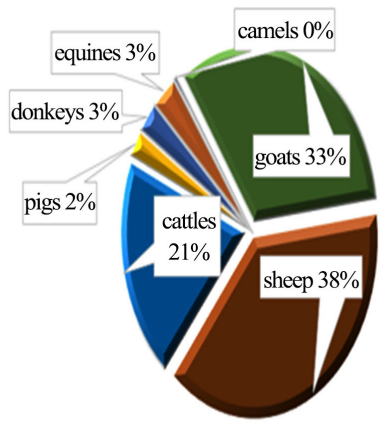

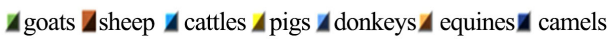

Figure 7. Percentage graph of the animals to which one could valorize $90 \%$ of their dung.

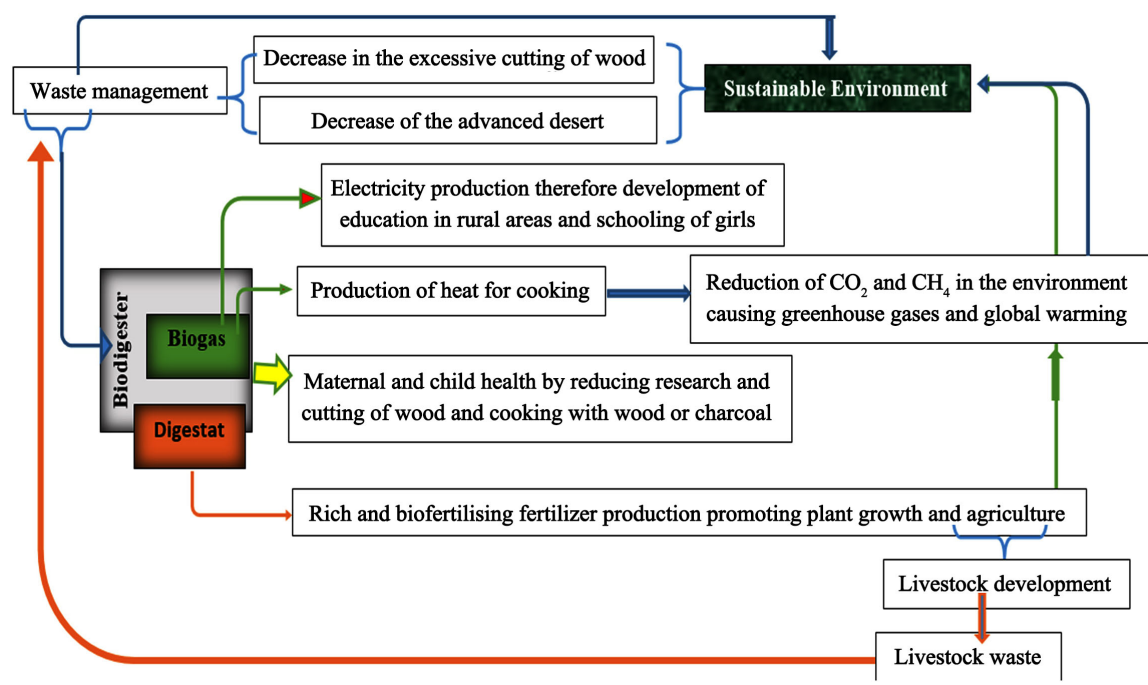

Figure 8. Solution approach in the waste management system focused on biogas production and sustainable development mechanism in the rural world.

organic matter in anaerobic (airless) medium. The gases released (mainly methane, $\mathrm{CH}_{4}$ ) have an impact on the greenhouse effect 72 times greater than the same amount of $\mathrm{CO}_{2}$.

A pile of manure left in the open will also produce methane. That is why it is doubly important to recover it, on the one hand to limit its impact on global warming and on the other hand to produce fuel in a country like Chad where the energy problem is a problem for all. Almost all the energy consumed is made up of traditional energies (95\% in 2011). The country has the lowest per capita energy consumption in the world (0.16 toe) and $9 \mathrm{kWh}$ of electricity (2011) [25]. Biogas technologies introduced at the household level aim to provide clean and sustainable energy, thus reducing the use of firewood [45] [46]. Senegal has almost achieved this policy.

\section{Acknowledgements}

I thank in the first place Mrs. Salwa Haroun for her advice. We thanked Mr. Amadou BA and his wife Fatimata Bintou Aidara BA for their agreement to use 
their farm for scientific purposes. We also thank Mr. Akhay Hissen Sayar for his courage and hard work in producing the bio-digester and sampling cow dung. Finally, our thanks to the colleagues of the URANI laboratory.

\section{Conflicts of Interest}

The authors declare no conflicts of interest regarding the publication of this paper.

\section{References}

[1] Neshat, S.A., Mohammadi, M., Najafpour, G.D. and Lahijani, P. (2017) Anaerobic Co-Digestion of Animal Manures and Lignocellulosic Residues as a Potent Approach for Sustainable Biogas Production. Renewable and Sustainable Energy Reviews, 79, 308-322.

[2] Battista, F. and Bolzonella, D. (2019) Exploitation of Solar Energy for Ammonium Sulfate Recovery from Anaerobic Digestate of Different Origin. Waste and Biomass Valorization. (In Press)

[3] Keck, M., Mager, K., Keller, K.W.M., Steiner, M.F.B. and Schrade, S. (2018) Odour Impact from Farms with Animal Husbandry and Biogas Facilities. Science of the Total Environment, 645, 1432-1443. https://doi.org/10.1016/j.scitotenv.2018.07.182

[4] Afilal, M.E., Moncif, M. and Benyamna, A. (2007) Valorisation des déchets organiques par fermentation méthanique. Revue des Energies Renouvelables, 9-12. https://www.cder.dz/download/cer07_2.pdf

[5] Schievano, A., D’Imporzano, G. and Adani, F. (2009) Substituting Energy Crops with Organic Wastes and Agro-Industrial Residues for Biogas Production. Journal of Environmental Management, 90, 2537-2541. https://doi.org/10.1016/j.jenvman.2009.01.013

[6] Dr. Afilal, M.E., Belkhadir, N. and Merzak, Z. (2013) Biogas Production from Anaerobic Digestion of Manure Waste: Moroccan Case. The Global Journal of Science Frontier Research, 13.

[7] Afilal, M.E., Elasri, O. and Merzak, Z. (2014) Caractérisations des déchets organiques et évaluation du potentiel biogaz [Organic Waste Characterization and Evaluation of Its Potential Biogas]. Journal of Materials and Environmental Science, 5, 1160-1169.

[8] Wannasek, L., Ortner, M., Amon, B. and Amon, T. (2017) Sorghum, a Sustainable Feedstock for Biogas Production? Impact of Climate, Variety and Harvesting Time on Maturity and Biomass Yield Research Paper. Biomass and Bioenergy, 106, 137-145. https://doi.org/10.1016/j.biombioe.2017.08.031

[9] Charnay, F. (2005) Compostage des déchets urbains dans les Pays en Développement: Elaboration d'une démarche méthodologique pour une production pérenne de compost. Université de Limoges, Limoges.

[10] Moletta, M. (2005) Caractérisation de la diversité microbienne aéroportée des biogaz. Thèse doctorat, Université de Montpellier, Montpellier.

[11] Kalloum, S., Boubdessalem, H., Touzi, A. and Iddou, A. (2006) La digestion anaérobie des boues des stations d'épuration: Une opportunité énergitique et environnementale. Mémoire de Magister, École Nationale Polytechnique d’Oran, Es-Senia.

[12] Société Française de Santé Publique (1999) L'incinération des déchets et la Santé Publique: Bilan des connaissances récentes et évaluation du risque. Collection Santé 
\& Société, Paris.

[13] Rodier, J. (1984) L'analyse de l'eau: Eaux naturelles, eaux résiduaires et eau de mer. 8 ème Edition, Dunod, France.

[14] Ohannessian, A. (2008) Composés Organiques Volatils du Silicium: Un frein à la valorisation énergétique des biogaz "Genèse et mécanismes de formation". Thèse de doctorat, École doctorale de Chimie de Lyon, 305p.

[15] Afilal, M.E., Bakx, A., Belakhdar, N. and Membrez, Y. (2010) Evaluation of the Biogas Potential of Organic Waste in the Northern Provinces of Morocco. Revue des Energies Renouvelables, 13, 249-255.

[16] Feng, L., Ward, A.J., Moset, V. and Møller, H.B. (2018) Methane Emission during On-Site Pre-Storage of Animal Manure Prior to Anaerobic Digestion at Biogas Plant: Effect of Storage Temperature and Addition of Food Waste. Journal of Environmental Management, 225, 272-279. https://doi.org/10.1016/j.jenvman.2018.07.079

[17] Singh, P., Sharma, S., Baral, B., Khatiwada, N.R. and Shakya, S.M. (2019) Assessing the Effect of Temperature on Performance of the High Altitude Anaerobic Digesters. In: Ghosh, S., Ed., Waste Valorisation and Recycling, Springer, Singapore, 487-495. https://doi.org/10.1007/978-981-13-2784-1_46

[18] Garfí, M., Castro, L., Montero, N., Escalante, H. and Ferrer, I. (2019) Evaluating Environmental Benefits of Low-Cost Biogas Digesters in Small-Scale Farms in Colombia: A Life Cycle Assessment. Bioresource Technology, 274, 541-548. https://doi.org/10.1016/j.biortech.2018.12.007

[19] Diallo, M.L. (2008) Les énergies renouvelables entant que facteur d'atténuation des GES-Cas de la Guinée. Evaluation Environnemental et Energie. Conférence.

[20] Kossmann, W., Pönitz, U., Habermehl, S., Hoerz, T., Krämer, P., Klingler, B., Kellner, C., Wittur, T., Klopotek, F.V. and Krieg, A. (1988) Biogas Basics: Eschborn. Biogas Digest, 1, 1-46.

[21] Rapport Final (2013) Etude d'etablissement d'une base de reference pour le projet biogaz. Programme de Structuration du Marché des Boues de Vidange en faveur des ménages démunis de Pikine et Guédiawaye (PSMBV). Office National de L'Assainissement du Senegal.

[22] Asmare, M. (2014) Design of Cylindrical Fixed Dome Bio Digester in the Condominium Houses for Cooking Purpose at Dibiza Site, East Gojjam Ethiopia. American Journal of Energy Engineering, 2, 16-22.

[23] Amingun, B., Parawira, W. and Musango, J. (2012) Anaerobic Biogas Generation for Rural Area Energy Provision in Africa. InTech.

[24] FAO Régional Office for Africa. http://www.fao.org/africa/news/detail-news/en/c/1128900/

[25] Richard, M.P. (2016) Rapport National du Tchad Préparation du rapport national pour la formulation et la rédaction du Livre Blanc Régional sur l'Accès aux services énergétiques intégrant les énergies renouvelables et l'efficacité énergétique.

[26] Rapport Agence Nationale de la Statistique et de la Demographie (2018) Situation Economique et Sociale du Sénégal en 2015.

[27] Diouf, B. and Miezan, E. (2018) The Biogas Initiative in Developing Countries, from Technical Potential to Failure: The Case Study of Senegal. Renewable and Sustainable Energy Reviews, 101, 248-254. https://doi.org/10.1016/j.rser.2018.11.011

[28] Document Installation Biogaz auto-construite ou Comment rouler avec du caca. 
Version $1.5 \mathrm{du} 01 / 06 / 2013$.

[29] Jack, W., White, W., McGrew and Sutton, M.R. (1978) Symposium Papers: Energy Rom Biomass and Wastes. Institute of Gas Technology, Vol. 1, USA.

[30] Rapport Final (2009) Guide methodologique pour le suivi d'une installation de methanisation. Etude réalisée pour le compte de l'ademe par l'apesa et biomasse normandie, Coordination Technique: Guillaume Bastide-Département Gestion Optimisée des Déchets-Direction Déchets et Sols-ADEME Angers.

[31] Regattieri, A., Bortolini, M., Ferrari, E., Gamberi, M. and Piana, F. (2018) Biogas Micro-Production from Human Organic Waste-A Research Proposal Article Sustainability (CC BY) Licence. http://creativecommons.org/licenses/by/4.0/

[32] Trazié Guy-Maxime IRJE BI (2007) Etude technique d'une unite de biometanisation destinee a l'electrification rurale: application au monastere de keur moussa. Ecole Supérieure Polytechnique Centre de Thies Departement Genie Mecanique Projet de fin d'Etudes.

[33] https://fr.weatherspark.com/y/78321/M\%C3\%A9t\%C3\%A9o-habituelle-\%C3\%A0Ndjamena-Tchad

[34] Njogu, P., Kinyua, R., Muthoni, P. and Nemoto, Y. (2015) Biogas Production Using Water Hyacinth (Eicchornia crassipes) for Electricity Generation in Kenya. Energy and Power Engineering, 7, 209-216.

[35] https://www.au-senegal.com/le-climat-et-la-meteo,046.html

[36] Okewale, A.O., Omoruwou, F. and Anih, C.E. (2018) Production of Biogas from Co-Digestion of Cow Dung, Saw Dust and Maize Husk. Advances in Chemical Engineering and Science, 8, 113-123. https://doi.org/10.4236/aces.2018.83008

[37] Al-Rousan, A. and Zyadin, A. (2014) A Technical Experiment on Biogas Production from Small-Scale Dairy Farm. Journal of Sustainable Bioenergy Systems, 4, 10-18. https://doi.org/10.4236/jsbs.2014.41002

[38] Abarghaz, Y., El Ghali, K.M., Mahi, M., Werner, C., Bendaou, N., Fekhaoui, M. and Abdelaziz, B.H. (2013) Modelling of Anaerobic Digester Biogas Production: Case Study of a Pilot Project in Morocco. Journal of Water Reuse and Desalination, 3, 381-391.

[39] Gungor, K. and Karthikeyan, K.G. (2005) Influence of Anaerobic Digestion on Dairy Manure Phosphorus Extractability. American Society of Agricultural and Biological Engineers, 48, 1497-1507. https://doi.org/10.13031/2013.19182

[40] Hammad, E.I., Al-Agha, M.R. and El-Nahhal, Y. (2019) Influence of Biogas Production on Bioremediation of Animal Manures. American Journal of Analytical Chemistry, 10, 1-8.

[41] Habouzit, F., Gévaudan, G., Hamelin, J., Steyer, J.P. and Bernet, N. (2010) Influence of Support Material Properties on the Potential Selection of Archaea during Initial Adhesion of a Methanogenic Consortium. Bioresource Technology, 102, 4054-4060. https://doi.org/10.1016/j.biortech.2010.12.023

[42] Ceballos, G., Ehrlich, P.R., Barnosky, A.D., Garcia, A., Pringle, R.M. and Palmer, T.M. (2015) Accelerated Modern Human-Induced Species Losses: Entering the Sixth Mass Extinction. Science Advances, 1, e1400253. https://doi.org/10.1126/sciadv.1400253

[43] Hammad, E., Al-Agha, M.R. and El-Nahhal, Y. (2018) Enhancing Biogas Production: Influence of Mixing Cow and Chicken Manures. Energy and Power Engineering, 10, 383-397. https://doi.org/10.4236/epe.2018.108024

[44] FAO 2019 Exploiter le potentiel du bétail pour stimuler le développement durable. 
http://www.fao.org/news/story/fr/item/1158107/icode/

[45] Tumutegyereize, P., Ketlogetswe, C., Gandure, J. and Banadda, N. (2017) Technical Evaluation of Uptake, Use, Management and Future Implications of Household Biogas Digesters-A Case of Kampala City Peri-Urban Areas. Computational Water, Energy, and Environ-Mental Engineering, 6, 180-191. https://doi.org/10.4236/cweee.2017.62013

[46] Mulinda, C., Hu, Q. and Pan, K. (2013) Dissemination and Problems of African Biogas Technology. Energy and Power Engineering, 5, 506-512.

https://doi.org/10.4236/epe.2013.58055 